\title{
Implementing an Android-based Learning Media Application to Improve Learners' Ability in Pronouncing Ending -s
}

\author{
Vina Fathira $^{1)}$, Silvia Utami ${ }^{1)}$ \\ ${ }^{1}$ Sekolah Tinggi Ilmu Bahasa Asing (STIBA) Persada Bunda \\ email: vinafathira@persadabunda.ac.id \\ email: silvia.utami@persadabunda.ac.id
}

\begin{abstract}
This research was done based on the needs to improve the learners' ability in pronunciation of ending $-\mathrm{s}$ by using android based application. Android based becomes popular in this era since gadget applies many applications to improve English language proficiency. The aim of the research is to implement the application on android based to improve the learners' ability in pronouncing ending $-\mathrm{s}$ and to find the influencing factors of the improvement. The method of this research was qualitative. This Classroom Action Research was conducted at eight second-year-learners in academic year 2018/2019 at STIBA Persada Bunda Pekanbaru. There were tests, fieldnotes, observation, and interview used in the data collecting techniques in this research. The result shows that implementing the application existed on android based learning media to improve learners' ability in pronouncing ending $-\mathrm{s}$ has significantly improved. It can be seen that the learners' ability in pronouncing ending $-\mathrm{s}$ are at the "fairly good" level category with score 56,67 increases to the "good" level category with score 73,75. Some influential factors towards the learners' improvement were affected by the students' willingnes to practice differentiating the base form of word given and continuous listening practice to the application which was aimed to obtain the information during the teaching-learning process. In conclusion, the implementation of application on android based can improve the learners' ability in pronouncing ending $-\mathrm{s}$.
\end{abstract}

Keywords: Application, Android, Pronunciation, Ending -s, Classroom Action Research

\begin{abstract}
Abstrak
Penelitian ini didasari oleh kebutuhan untuk meningkatkan kemampuan mahasiswa dalam pengucapan akhiran -s pada aplikasi berbasis android. Aplikasi berbasis android menjadi popular pada era ini karena gadget menawarkan banyak aplikasi untuk meningkatkan kemampuan bahasa Inggris. Tujuan dari penelitian ini untuk mengimplementasikan aplikasi berbasis android dan untuk mencari faktor-faktor yang mempengaruhi peningkatan tersebut. Metode penelitian ini adalah kualitatif. Penelitian Tindakan Kelas diterapkan pada penelitian ini pada 8 orang mahasiswa pada tahun kedua pada tahun ajaran 2018/2019 di STIBA Persada Bunda Pekanbaru.Terdapat tes, catatan harian, pengamatan dan interview dalam tehnik pengumpulan data. Hasilnya menunjukkan bahwa pengimplementasian aplikasi berbasis
\end{abstract}


android untuk meningkatkan kemampuan mahasiswa dalam pengucapan akhiran -s meningkat secara signifikan. Hal tersebut dapat dilihat dari kemampuan mahasiswa dalam memahami pengucapan akhiran -s dari kategori cukup atau (fairly good) dengan skor 56,67 meningkat menjadi kategori baik (good) dengan skor 73,75. Beberapa faktor yang mempengaruhi peningkatan mahasiswa tersebut yakni mereka lebih sering praktek dengan menggunakan aplikasi tersebut untuk membedakan bunyi dari bentuk dasar dari kata yang diberikan dan mendengarkan berkali-kali dari aplikasi yang disediakan untuk memperoleh informasi selama proses belajar mengajar. Oleh karena itu, implemenatsi dari aplikasi berbasis android dapat meningkatkan kemampuan mahasiswa dalam pengucapan akhiran - s.

\section{Kata Kunci: Aplikasi, Android, Pengucapan, Akhiran-s, Penelitan Tindakan Kelas}

\section{INTRODUCTION}

In learning English, the teachers usually face challenges to find the latest or the newest information, strategy, and application to support the needs in the classroom. Due to those problems, the development of technology android based becomes a solution to find all things to support the learning in twenty first century or well-known as millennial era. Implementation of learning media as android based that is part of ICT or Information, Communication, and Technology) focuses on the learners, community in the classroom, creation and the delivering the suitable material (Goh: 2009).

It is needed to be developed since the ability in speaking English as foreign language in Indonesia becomes important point and for everyone should give the chance to learn English (Lauder: 2008). Moreover, if the learners learn the active skill as speaking skill, especially in pronunciation, it will need the knowledge of phonetic and phonology. The knowledge of phonetic and phonology related to the oral proficiency (Chen and Gowsami (2010). In other words, the ability of oral proficiency can be seen from the ability in pronouncing well of each word in English.
Eventhough, the differenciation of sound variation of word happens because of the different cultural background (Winarno and Bandjarjani: 2008; Siahpoosh: 2008). It means that the pronunciation in speaking English very important to pay attention to be analysed. The important points in Speaking English are phonetic and phonology matters eventhough there will be differenciation of sound variation due to the cultural background.

In line with the problem while teachinglearning process, the researchers identified the pronunciation problem in making mistake in pronouncing ending $-\mathrm{s}$, minimal pair, and others. It is hardly for the learners to differenciate how to pronounce the correct pronuncatian. To solve the problem, the researchers was interested in conducting a research especially in pronouncing ending $-\mathrm{s}$ by implementing the application existed on learning media as android based to the fourth semester learners at STIBA Persada Bunda. Implementation of learning media is assumed to be effective in improving the learners' interest and attention in pronunciation since the applications on android based learning media could be easily applied. There are some sources stated that implementation of learning media through application can bring easiness to be applied, memorise the lesson, 
and elaborate the brain and mental of the learners by implementing the suitable application (Rofiyarti and Sari: 2017; Kurniawan; 2008). However, the researchers limited the use of android application in pronunciation. Hence, the title of this article is "Implementing an Android-based Learning Media Application to Improve Learners' Ability in Pronouncing Ending -s".

Two important points are formulated in this study; (a) How good the implementation of application in android based learning media can improve the learners' ability in pronouncing ending $-\mathrm{S}$ of fourth semester learners at STIBA Persada Bunda Pekanbaru?, (b). What are the factors influencing the learners' improvement in pronouncing ending $-\mathrm{s}$ of fourth semester learners at STIBA Persada Bunda Pekanbaru by implementing the application existed on android based learning media?

Some related theories are discussed and presented in the following information:

\section{The Benefit of Tehcnology}

Information and Communication Technology or called as ICT, that told about the technology which is having the application in order to share information and communication from personal or organization through time and spatial (Dettori and Persico: 2011). In using technology, the user should pay attention to these five principles. First, the technology should give the opportunity to read, write and discuss; second the technology should make the learners more focus; third the technology should give the time; fourththe technology should give the learners made error and self-correctness; and fifth the technology should give the chances to explore their pronunciation (Erben, Ban, and Castaneda: 2009). However, to avoid misleading while using technology, the user should outline some points that become attention before applying technology in the teaching-learning process. Firstly, it is better for the teachers to check the application to make sure everything is understandable before starting the class. Secondly, the teacher should make the regulation while using this technology, like the forbidden words are banned in that school (Mahmudah: 2015).

\section{Pronunciation Ending $-s$}

The word 'pronunciation' refers to English phonology terms as one of it is International Phonetic Association (IPA) transcription. This International Phonetic Association (IPA) transcription is needed and very important because it is a tool to use to transcribe the alphabet in general. (Ogden: 2009; Gut: 2009). Accordance with the previous statements, the word 'pronunciation' defines the way or rules in spellings on vocal sound and consonant sounds (Alan: 2014).

Except explaining on the transcription, the researchers tried to outline a brief explanation on the pronunciation ending $-\mathrm{s}$. The problem of pronouncing $-\mathrm{s}$ always existed in pronunciation of plurals, thirdperson verbs, and contractions existingin the ends of words.According Dale and Poms (2005) stated that there are the rules to avoid the problems in pronouncing plurals, third-person verbs, and contractions. It can be seen as follows. First, the ending $-\mathrm{s}$ forming the plural, the third-person, and contraction will always sound like /s/ when the last sound of the base form is voiceless sound.Second, the ending $-\mathrm{s}$ forming the plural, the thirdperson, and contraction will always sound like /z/ when the last sound of the base form is voiced sound.Third, the ending $-\mathrm{s}$ forming the plural, the third-person, and contraction will always sound like /Iz/ when 
the last sound of the base form is sibilant sounds. These three rules have dealt with the knowledge of phonological terms like voiceless, voiced, and sibilant sound. To know more about these terms in phonology, the learners should learn first about all sounds.

\section{Related Findings}

In this part, the researchers took these related findings that used technology in learning English. The related findings that can emphasize this research can be seen as follows.

The first related finding was about to know the way to develop an application android based. It was developed to support the pronunciation in higher education and to implement the application (Anggraini, Novianti, and Bardadi: 2018). The result showed that all respondents were able to understand and apply the application well. The similarity of this previous research to this research was about the pronunciation related to application android based. The difference of this previous research to this research was not in designing an application but in implementing the application existed on the learning media of android based.

The second related finding was about teaching English especially in pronunciation. The result showed that the teachers English as Second language believed that the pronunciation ability should teach integratedly to other skills of English (Shah, Othman, and Senom: 2017). The other result showed that the teachers believed that focused on the pronunciation matter different to the curriculum distributed in school. The similarity of this previous research to this research focused on the pronunciation and used an application. The difference of this previous research to this research was the application used.

The last related finding was about the Duo lingo application applied in pronunciation (Mahmudah: 2015). The result showed that this application was effective to improve the learners' ability in pronunciation in basic level. The similarity of this previous research to this research focused on the pronunciation that was used application existed in android. The difference of this previous research to this research was not applying the Duolingo application as an action research however this research used Pronunciation application to improve the learners' ability in pronunciation on the application existed on the android based learning media.

\section{METHOD}

\section{Research Design}

In this research, the researchers used a Classroom Action Research by Kemmis and McTaggart (2014:11). It can be seen in the Figure 1 below.

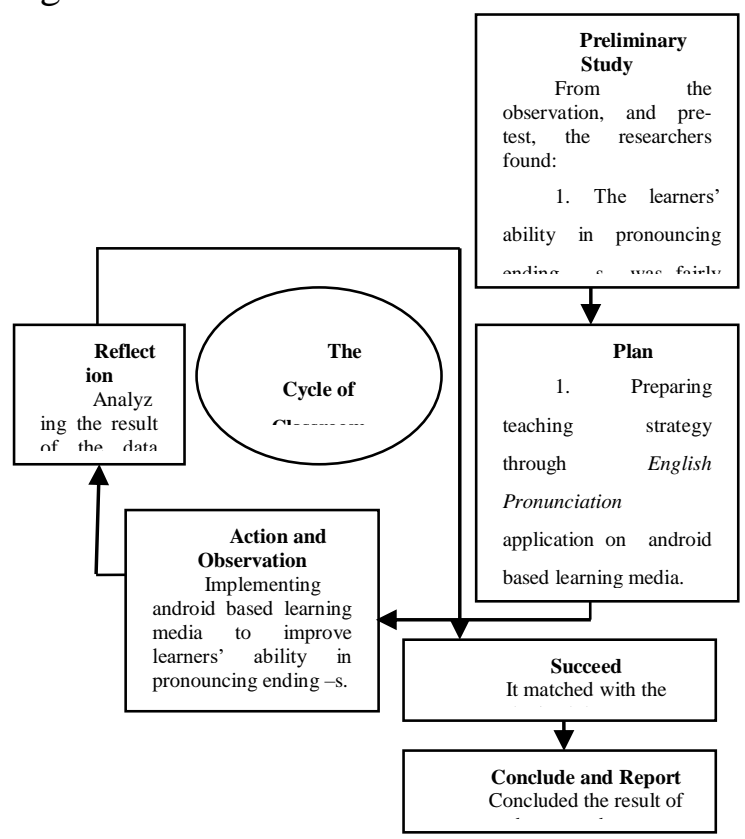

Figure 1. Research Design 
From the figure above, the stages of the research were started at preliminary study, like gain the information of the learners' ability in pronouncing ending $-\mathrm{s}$ in "fairly good" level. By implementing the android based learning media, the researchers focused on English Pronunciation application existed on android based learning media chosen based on the aim of this research. After that, the researchers prepared the planning to implement the android based learning media. At this stage, the planning were teaching strategy, syllabus per semester, and the minimum score of achivement. Then, the researchers did the action. At this stage, the researchers applied teaching strategy by implementing android based learning media that had already prepared before. Furthermore, the next stage was observation. At this stage, the collaborator of the research conducted observation of the teaching-learning activities in the classroom and wrote all activities during teaching-learning process. The last stage was reflection. At this stage, the researchers and collaborator did the reflection and evaluation of the implementation of android based learning media in teaching English phonology to improve the learners' ability in pronouncing ending $-\mathrm{s}$.

Based on the explanation above, the researchers created 6 meetings for one cylce of the research. The researchers divided into 4 meetings for teaching-learning process by implementing the application existed on android based learning media, 1 meeting for pre-test and 1 meeting for posttest to evaluate the learners' achievement and learners' ability in pronouncing of ending $-\mathrm{s}$ by implementing the application existed on android based of English phonology subject. The researchers only applied 1 cycle since it was already improvement of learners' ability in pronouncing ending $-\mathrm{s}$ by implementing the application existed on android based in English phonology subject and applied in higher education level with limited number of meeting.

\section{Location and Participants}

This research was conducted at STIBA Persada Bunda located at Diponegoro street number 42 Pekanbaru, Riau. The researchers chose purposive sampling in selecting participants. The participants of this research were the fourth semester learners at STIBA Persada Persada Bunda in academic year 2018/2019 attending English phonology subject. The researchers focused on the pronunciation of ending $-\mathrm{s}$.

\section{Technique Collecting Data}

The research instruments of this research in order to collect the data by using test, fieldnotes, checklist, observation and interview. To obtain data related to understand thepronunciation of ending $-\mathrm{s}$, the learners were asked to answer a 30 question of multiple choice questions by implementing the English Pronunciation application existed on android based learning media relating to the pronunciation of ending $-\mathrm{s}$. It aimed to evaluate the improvement of the learners' ability in understanding pronunciation of ending $-\mathrm{s}$ by implementing android based learning media, especially in using Pronunciation application. Then, the researchers and collaborator wrote all activities in English phonology subject by using fieldnotes and obeservation checklist in accordance with the activities done in classroom. After that, the researchers conducted interview to all learners to obtain additional information in order to find out the learners' feeling, the learners' response while the teachinglearning process by implementing the application existed on android based 
learning media in pronunciation of ending s. The aim of this interview to obtain data about the factors affected the improvement of the learners' ability in pronouncing of ending $-s$ by implementing the application existed on android based learning media.

\section{Technique Analyzing Data}

After collecting the data, the researchers evaluated and analyzed post-test by counting the number of correct answer and by calculating it to the final score (post-test) of each learner. There minimum score was about 65 . In short, if the post-test which was taken from reflection were higher the minimum score or even much better than the pre-test which was taken from preliminary study that can be seen in Diagram 1 about research design. It meant that there would be an improvement of learners ability in pronouncing of ending $-\mathrm{s}$ by implementing the English Pronunciation application existed on android based. To find the final score of each learner, the researchers used this formula below (Fathira: 2017).

$\mathrm{M}=\frac{\mathrm{X}}{\mathrm{N}}$

$\mathrm{M}=$ mean score

$\mathrm{X}=$ correct answer

$\mathrm{N}=$ Number of all items

Then, the score will be converted to the level of category based on the STIBA Persada Bunda range score. If the range score is about $100-80$, it means that the level of category is in "very good" level; if the range score is about 79-65, it means that the level of category is in "good" level; if the range score is about $64-55$, it means that the level of category is in "fairly good" level; if the range score is below 55, it means that the level of category is in "poor" level.

\section{FINDING AND DISCUSSION}

In this part, the researchers described the stages that had been mentioned before as planning, observation, reflection, and action. Since the aim of this research was to improve the learners' ability in pronouncing ending $-\mathrm{s}$ by implementing the application existed on android based learning media. This is due to the learners' ability in pronouncing ending $-\mathrm{s}$ was still categorized below standard. The researchers explained the stages that were done in the teaching-learning process in the classroom of 4 meetings as described below. In addition to, there was 1 meeting for pre-test and 1 meeting for post-test.

\subsection{Meeting for Pre-Test}

In this meeting, the researchers did a pre-test to the learners. It was for gaining the information about the learners' ability in pronouncing ending $-\mathrm{s}$ by implementing the application existed on android based learning media. The information of the learners' ability in pronouncing ending $-\mathrm{s}$ by implementing the English Pronunciation application existed on android based learning media was in "fairly good" level by score 56,67. Since the learners' ability was indicated below standard, the researchers tried this application existed on android based learning media to improve the learners' ability in pronouncing ending $-\mathrm{s}$.

\subsection{The Result of First Meeting}

Before doing this first meeting, the researchers had been looking for information about thelearners' ability in pronouncing ending $-\mathrm{s}$. Then, at the first meeting in the classroom, the teaching-learning process was preceded by an introduction to the learners about the the pronunciation of ending $-\mathrm{s}$. The researchers asked the questions and asked opinion to the learners about pronouncing ending $-\mathrm{s}$. The problem existed in 
pronouncing plurals, third-person verbs, and contractions that existed in pronunciations of ending $-\mathrm{s}$ in the ends of words. There are some rules to avoid the problem in pronouncing those plurals, third-person verbs, and contractions based on the Pronunciation's book.

After that, the researchers gave the example of pronouncing ending -sfirst then followed by the rules and examples of pronouncing ending -sto the learners. After that, the learners were asked to pronounce other words or other examples of pronouncing ending $-\mathrm{s}$. The researchers asked learners to write down everything that became the important point to the rules of pronouncing ending $-\mathrm{s}$. The rules can be seen as follows.

1. First, the ending $-\mathrm{s}$ forming the plural, the third-person, and contraction always sound like /s/ when the last sound in the base form is voiceless.

2. Second, the ending $-\mathrm{s}$ forming the plural, the third-person, and contraction always sound like /z/ when the last sound in the base form is voiced.

3. Third, the ending $-\mathrm{s}$ forming the plural, the third-person, and contraction always sound like /Iz/ when the last sound in the base form is sibilant sounds.

These rules have to deal with the knowledge of phonological terms like voiceless, voiced, and sibilant sound. To know more about these terms in phonology, the learners should learn first about all sounds.

\subsection{The Result of Second Meeting}

After that, in the second meeting, the researchers explained more deeply by giving examples of voiceless, voiced, and sibilant sounds by implementing the application existed on android based learning media. The researchers introduced two applications used in this research. The researcher asked the learners to download the online and offline of English Pronunciation application of pronunciation by sharing the internet acces from the researchers. The applications were pronunciation application, offline and online. After downloading the two applications of pronunciation, the learners were asked to use the application to ease them apply these English Pronunciation applications in the following meetings. Before continuing to the next meeting, the researchers asked the learners to practice at home by giving several words related to the pronunciation of ending $-\mathrm{s}$ by implementing the application given to them.

\subsection{The Result of Third Meeting}

In the third meeting, the learners were asked to explain what they did at home as the theindividual assignment given at the previous meeting, like explaining the way to pronounce the selected words of examples by implementing the two applications existed on android based learning media.

After that, the researchers gave response to the results of learners' assignments by correcting the way to acces, the way to pronounce, and the reason of pronouncing ending $-\mathrm{s}$ whether the last sound of base form was voiced, voiceless, or sibilant sound. The researacher gave the detail information of voiced, voiceless, and sibilant sounds of other examples. However, the researchers only describedthe limited example of voiced, voiceless, and sibilant sounds.

After giving comments and inputs due to the learners' assignments of voiced, voiceless, and sibilant sounds, the researchers instructed learners to think of their mispronouncing words by implementing the application existed on 
android based learning media again, paid attention to the last sound of base form, pronounced again ending $-\mathrm{s}$ well. This process aimed to eliminate misunderstandings in pronouncing ending $\mathrm{s}$ of the learners to the last sound of base form.

\subsection{The Result of Fourth Meeting}

After that, in the fourth meeting, the researcher focused on showing the results of the two applications existed on android based learning media in pronouncing ending $-\mathrm{s}$ that had been observed previously. This activity can be an overview to the learners' understanding of pronouncing ending $-\mathrm{s}$ on what they did before. In this meeting, the learners were asked to stand in front of the class and used their own android to implement the application existed on learning media. The researchers asked the learners read one by one of the selected words of ending $-\mathrm{s}$. In this meeting, the learning process was focused on showing the result of two applications on android based learning mediathat have been observed. Based on these points, the learners had got the enough information regarding to the pronunciation of ending $-\mathrm{s}$ by implementing the application existed on android based learning media.

\subsection{Meeting Post-Test}

In the last meeting, the post-test also known as cycle test was conducted by asking the learners to complete the test regarding to learners' ability in pronouncing ending $-\mathrm{s}$. The learners were asked to answer a set multiple choice questions about 30 question of ending $-\mathrm{s}$ by implementing or using the applications given to the students. This test was held to measure the learners' achievement in understanding the concept of pronouncing ending $-\mathrm{s}$. After giving the test, the researchers tried to evaluate the learners' work that can be seen in the following Table 1.

Table 1 Result of the Post-Test in Pronouncing Ending $-\mathrm{s}$

\begin{tabular}{lll}
\hline No. & \multicolumn{1}{c}{$\begin{array}{c}\text { Learner's } \\
\text { Score }\end{array}$} & \multicolumn{1}{c}{$\begin{array}{c}\text { Category of } \\
\text { Ability }\end{array}$} \\
\hline 1 & 93,33 & Very Good \\
2 & 93,33 & Very Good \\
3 & 86,67 & Very Good \\
4 & 76,67 & Good \\
5 & 70,00 & Good \\
6 & 66,67 & Good \\
7 & 53,33 & Poor \\
8 & 50,00 & Poor \\
\hline Mean $=\mathbf{7 3 , 7 5}$ & Good \\
\hline
\end{tabular}

\subsection{Learners' Achievement}

Based on the data collection from the pre-test above as the cycle test, it is found that the mean score is significantly increased and categorized as good with score 73,75 . It can be seen as the previous test in the pre-test was 56,67 is still low and categorized fairly good. In conclusion, after conducting the research by implementing of learning media android based for four meetings (1 cycle), the learners' mean score was $\mathbf{7 3 , 7 5}$ and categorized as good. It can be seen in the following Figure 2 below. The Learners' Ability of Post-
Testof Pronouncing Ending $-s$

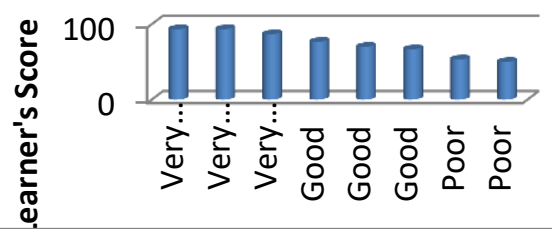

Figure 2. Result of Post-Test in Pronouncing Ending $-\mathrm{s}$ 
Moreover, the researchers found that the learners still have lack of understanding of the rules in pronouncing ending $-\mathrm{s}$ that can be seen from the resut of pre-test. Most learners get low score that are categorized as poor with $25 \%$. Meanwhile, one learner is categorized as fairly good with $12,5 \%$. Then, one learner is categorized as good with $12,5 \%$. Last, two learners are categorized as very good with $25 \%$. It can be seen in the table 2 below:

Table 2 The Result of Pre-Test of Pronouncing Ending $-\mathrm{s}$

\begin{tabular}{|c|c|c|}
\hline No. & $\begin{array}{l}\text { Learner's } \\
\text { Score }\end{array}$ & $\begin{array}{c}\text { Category of } \\
\text { Ability }\end{array}$ \\
\hline 1. & 93.33 & Very Good \\
\hline 2 & 83.33 & Very Good \\
\hline 3 & 66.67 & Good \\
\hline 4 & 50.00 & Poor \\
\hline 5 & 46.67 & Poor \\
\hline 6 & 43.33 & Poor \\
\hline 7 & 36.67 & Poor \\
\hline 8 & 33.33 & Poor \\
\hline \multicolumn{2}{|c|}{ Mean $=56.67$} & Fairly Good \\
\hline
\end{tabular}

The scores from the Table 2 above are obtained from the calculation of the correct answer divided by the total number of questions then multiplied by 100 . From the data above, it shows that there are two learners who get very good with score 93,33 and 83,33; one learner who gets good with score 66,67, whereas five learners are categorized as poor, as Figure 3 below:

\section{The Learners' Ability of Pre-Test of Pronouncing Ending -s}

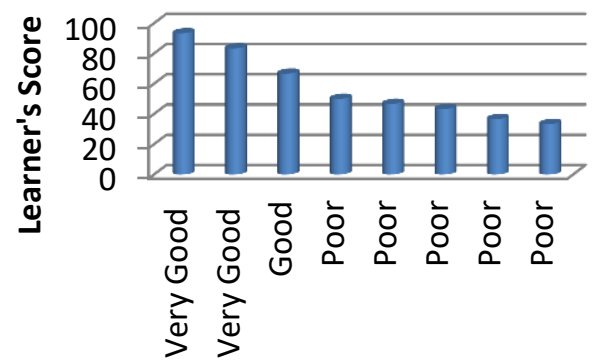

Figure 3. Result of Pre-Test of Pronouncing Ending $-\mathrm{S}$

From Figure 2, it shows that only 2 of 8 learners get the highest level of category in very good level, one of 8 learners gets the high level of category in good level, then the other 5 of 8 learners get the lowest level of category in poor level. Then, the comparison from the pre-test and post-test found that the learners' mean score is increased in numbers. It shows that from the pre-test, there are only 2 learners get very good level of category increases into 3 learners get very good level of category; there is only 1 learner gets good level of category increased into 3 learners goet good level of category; there are 5 learners get poor level of category decreases into only 2 learners get poor level of category. It can be seen in Table 3.

Table 3 The Comparison of Total of Participants and the Category Obtained

\begin{tabular}{llcl}
\hline No. & Test & $\begin{array}{c}\text { The } \\
\text { Number of } \\
\text { Participant }\end{array}$ & Category \\
\hline 1. & Pre-test of & 2 & Very Good \\
& Ending $-\mathrm{s}$ & 1 & Good \\
& & 5 & Poor \\
\hline 2. & Post-test & 3 & Very Good \\
& of Ending & 3 & Good \\
& $-s$ & 2 & Poor \\
\hline
\end{tabular}


In line with the Table 3 above, to compare the increasing numbers of learners improvement, it can be seen from the result of each part of questions in pronouncing ending $-\mathrm{s}$ taken from pre-test and post-test. The result can be seen in these two Figures 3 and 4 below.

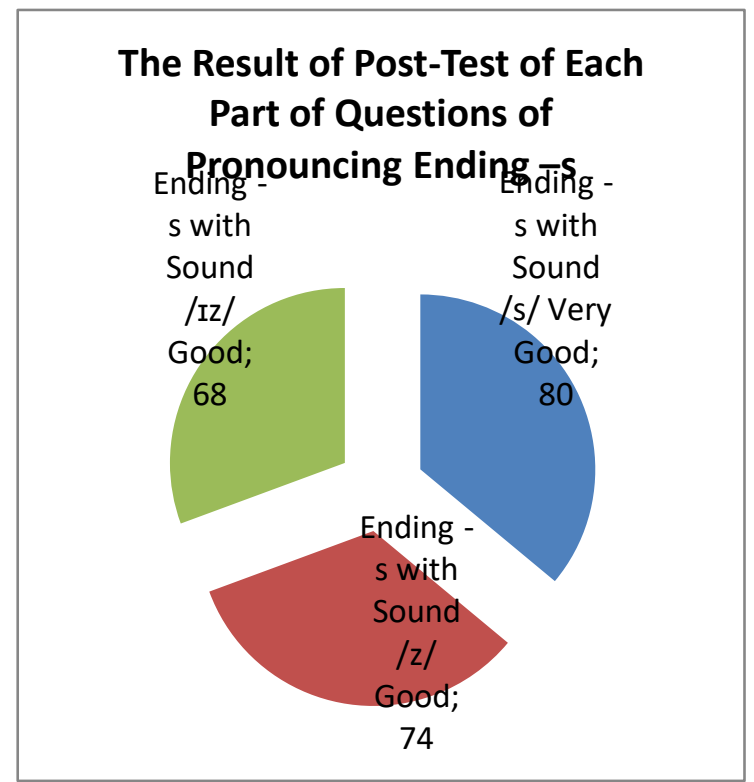

Figure 4. Result of Post-Test by Learners of Each Part of Questions of Pronouncing Ending $-\mathrm{S}$

The Figure 4 shows that the result of learners' post-test that assesses based on the three parts of questions is satisfactory. These three parts of questions are ending $-\mathrm{s}$ with sound /s/, ending $-\mathrm{s}$ with sound /z/, and ending $-\mathrm{s}$ with sound /Iz/. In Figure 3, it describes that the score from these parts of questions is good. The post-test result from ending $-\mathrm{s}$ with sound $/ \mathrm{s} /$ is categorized as good with score 80; the pre-test result from ending $-\mathrm{s}$ with sound $/ \mathrm{z} /$ is categorized as good with score 74 ; the pretest result from ending $-\mathrm{s}$ with sound /Iz/ is categorized as good with score 68 .

Furthermore, for the result of pre-test of each part of the question of pronouncing ending-s can be seen in the following figure 5.
The Result of Pre-Test of Each Part of Question of Pronouncing Ending -s

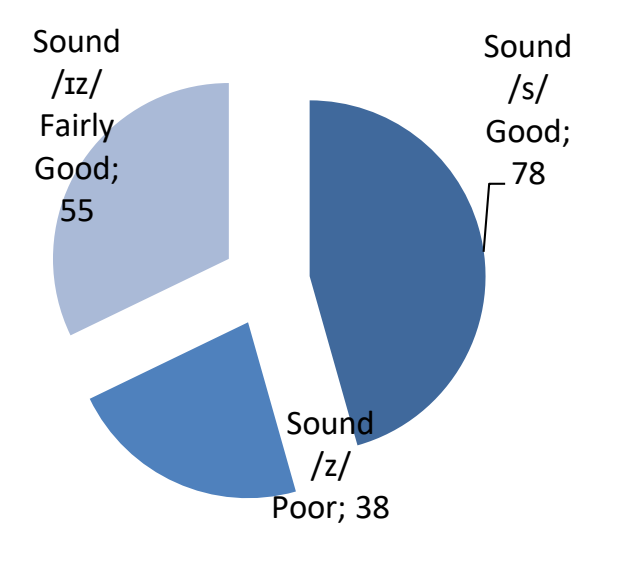

Figure 5. Result of Pre-Test by Learners of Each Part of Questions of Pronouncing Ending $-\mathrm{s}$

This Figure 5 shows that the result of learners' pre-test that assesses based on the three parts of questions is unsatisfactory. In Figure 4 , it describes that the score from these parts of questions is in different of level of category. The pre-test result from ending $-\mathrm{s}$ with sound /s/ is categorized as good with score 78; the pre-test result from ending $-\mathrm{s}$ with sound $/ \mathrm{z} /$ is categorized as poor with score 38; the pre-test result from ending $-\mathrm{s}$ with sound /Iz/ is categorized as fairly good with score 55 .

Based on the information presented in the paragraph above, it is clear that the scores from each part of questions shows significantly increased. The increasing of the learners' achievement can be seen from the result of pre-test to the result of posttest. The learners' post-test score is much higher than the pre-test one. It is concluded that there has been an improvement of the learners' ability in pronouncing ending $-\mathrm{s}$ by implementing the application existed on android based learning media. In other words, it can be argued that the 
implementation of android based learning media in pronouncing ending -s can help learners to better competency in pronunciation. This is in line with the factors influencing the improvement of implementing android based learning media that can be seen from the explanation below.

\subsection{Factors that Influenced the Improvement}

Furthermore, based on observation sheet results, the researchers found that every stage of implementing android based learning media was well done by learners. And then, during the interview, information was found that most learners were active in gaining information of the application and enjoyed during the teaching-learning process. However, there was one learner who got bored due to the access of the application existed on android based learning media since he used different types of android and so that it made him not enjoyed the teaching-learning process. It showed that there were other factors that influence the learners' ability in pronouncing ending $-\mathrm{s}$ and the factors that affected the learners' activity during the teaching-learning process other than the result of the test.

Based on the results gained in this first cycle of each research instrument, the researchers stated that the learners' ability of English Lettersof fourth semester learners at STIBA Persada Bunda in academic year 2018/2019 in pronouncing ending $-\mathrm{s}$ by implementing the android based learning media in a English phonology class was categorized into good level with score 73,75. Therefore, the researchers decided not to continue the research into the next cycle since the learners' score had reached over the minimum score and got specified successfull criteria.

The previous studies had done the research related to the implemention of android based learning media in pronouncing ending $-\mathrm{s}$. Therefore, the researchers summarized the previous research that is separately detailed into the application used and the focus in pronouncing ending $-\mathrm{s}$. For the pronounciation, the researchers found similarities in the analysis done by Anggraini, Novianti, and Bardadi (2018); Shah, Othman, and Senom (2017), and Mahmudah (2015) that was effective to improve pronunciation through application. It is good to implement android based learning media in pronunciation.

\section{CONCLUSION}

Based on findings and discussions in this research, it can be concluded that by implementing android based learning mediain pronouncing ending $-\mathrm{s}$ can help learners to improve learners' ability in pronouncing ending $-\mathrm{s}$. This can be seen by these points below.

The learners' mean score is 73.75 which was categorized into good level of category. This is based on ranges cores of 65-79 that categorized as "good". Factors influencing the improvement of learners' ability in pronouncing ending -sare the learners' interest in using theseapplication existed on android based learning media. In addition, the learners are active in pronouncing ending $-s$ in English phonology studies which are usually boring. However, only few learners get bad scores. This happened due to the different types of android used by the learner.

Furthermore, generally the application existed on android based learning media often used by the other researchers. They 
can prove it; it is effective way to used android based learning media. This is in line with the findings Anggraini, Novianti, and Bardadi (2018); Shah, Othman, and Senom (2017), and Mahmudah (2015). However, only the research conducted by Mahmudah (2015) is similar to this research. In relation to the results of the above points (point 5), the researchers then conduct a qualitative research that focuses on pronunciation of ending -ed. In addition to this research, the researchers need to choose other applications dealt with other subject in English to be examined in the future.

\section{ACKNOWLEDGMENTS}

The team would like to say thank to Kemenristekdikti which in this occasion gives researchers the chance to publish the research findings to a national journal. The findings of this study are part of Hibah Ristekdikti 2019 namely Penelitian Dosen Pemula 2019. In addition, researchers would thank for the team members who have been actively involved in this research.

\section{REFERENCES}

Alan, Cruttenden. 2014. Gimson's Pronunciation of English. Eighth Edition. London and New York: Routledge.

Anggraini, HestiWahyuni, H. Novianti, A. Bardadi. 2018. Pengembangan Bahan Ajar Berbasis Android untuk Meningkatkan Kemampuan Pengucapan pada Mahasiswa. CESS (Journal of Computer Engineering System and Science). p-ISSN: 2502-7131, e-ISSN: 2502-714x, Volume 3 Nomor 1. Retrieved from http://jurnal.unimed.ac.id/2012/index.ph p/cess/article/download/7854/7747.

Chen, Hsuan-Yu \& Jaya S. Gowsami. 2010. The Impact of Phonetic and Phonological Instruction on the Oral Proficiency of Spanish-speaking ESL Learners, The Asian EFL Journal, Special Edition, The $1^{\text {st }}$ Asian Cebu Conference, Time Taylor Press page 111-123. Ed. P. Robertson and R. Nunn.

Dale, Paulete and L, Poms. English Pronunciation Made Simple. New York: Pearson Education, 2005.

Dettori, Giulana and D. Persico. 2011. Fostering Self-Regulated Learning through ICT. Harshey and New York: Information Science Reference. Harshey and New York: Information Science Reference

Erben, Tony, R. Ban, and M. Castaneda. 2009. Teaching English Language Learners through Technology. New York: Routledge

Fathira, Vina. 2017. Analysis of EFL Students' Ability in Reading Vocabulary of Synonyms and Antonyms. Lectura: Jurnal Pendidikan, Vol 8 No.1 (2017). Retrieved from https://ejurnal.unilak.ac.id/index.php/lect ura/article/view/426/309.

Goh, Tiong T. 2009. Multiplatform ELearning Systems and Technologies: Mobile Devices for Ubiquitous ICTBased Education. Harshey and New York: Information Science Reference

Gut, Ulrike. 2009. Introduction to English Phonetics and Phonology. Frankfurt: Peter Lang, I nternationalerVerlag der Wissenschaften.

Kemmis, S., and McTaggart, R. 2014. The Action Research Planner. Revised Edition. Geelong: Deakin University Press.

Kurniawan, Yudha. 2008. Creative Games for Kids. Jakarta: Wahyu Media. 
Lauder, Allan. 2008. The Status and Function of English in Indonesia: A Review of Key Factors, Jurnal Makara, Sosial Humaniora, Vol. 12, No. 1, Juli 2008: 9-20. Depok: Universitas Indonesia.

Mahmudah, Laila. 2015. An analysis of Pronunciation Exercises in Duolingo Application and Its Contribution as English Learning Media". Thesis S1. Unpublished. Retrieved from http://eprints.walisongo.ac.id/5059/1/113 411023.pdf

Ogden, Richard. 2009. An Introduction to English Phonetics. Edinburgh: Edinburgh University Press.

Rofiyarti, Fitri, dan A. Y. Sari. 2017. "Tik untuk Aud: Penggunaan Platform "Kahoot!" dalam Menumbuhkan Jiwa Kompetitif dan Kolaboratif Anak", PEDAGOGI: Jurnal Anak Usia Dini dan Pendidikan Anak Usia Dini, Volume 3 Nomor 3b Desember 2017, pp 164-172.

Shah, Shanina Sharatol Ahmad, J. Othman, and F. Senom. 2017. The Pronunciation Component in ESL Lessons: Teachers' Beliefs and Practices. Indonesian Journal of Applied Linguistics, Vol. 6 No. 2, January 2017, pp. 193-203. Retrieved from http://ejournal.upi.edu/index.php/IJAL/ar ticle/view/4844.

Siahpoosh, Hossein. 2008. Pronunciation in EFL Classes and the Personality Factors in Learning Pronunciation. TEFLIN: 6th Asia TEFL International Conference, 13 Agustus 2008. Bali, Indonesia. 